\title{
DISCURSO DA SERVIDÃO VOLUNTÁRIA: relações de força e liberdade na obra de La Boétie
}

\author{
Volunteer service speech: relations of \\ power and freedom in La Boétie's work
}

Edson Donizete Toneti

Doutorando no programa de Teologia da School of Theology and Ministry do Boston College nos Estados Unidos, e-mail:adonizeti_toneti@hotmail.com

\begin{abstract}
Resumo
O objetivo deste artigo é propiciar um discernimento ante as ambiguidades suscitadas pelo Discurso da Servidão Voluntária no seu percurso histórico, desde seu nascedouro, passando pelas apropriações de determinados grupos, até as diferentes óticas de leitura. Na tentativa de compreender o porquê da servidão voluntária, Etienne de La Boétie reescreve as bases do poder à luz da Antiguidade, donde originam-se as relações de força. La Boétie tece considerações que permitem concluir que na tirania a cumplicidade, a igualdade e o companheirismo podem soar extremamente falsos. O antídoto mais eficaz no enfrentamento destes desvios, como forma de reencontrar a liberdade esquecida, é o bom exercício da amizade. A atualidade do Discurso da Servidão Voluntária reside no fato de ser um perene paradigma para a análise de todo e qualquer tipo de exercício da tirania.
\end{abstract}

Palavras-chave: Ambiguidade. Poder. Liberdade. Servidão. Voluntária. 


\section{Abstract}

The goal of this article is to reflect on the ambiguities raised by the Discourse of the Voluntary Servitude in its historic journey, from its origin through the appropriations by certain groups, to the different optical readings. As an attempt to understand why the voluntary servitude happens, Etienne de La Boétie rewrites the foundations of power, looking at ancient authors from whom the argument of the balance of power originated. La Boetie's arguments lead to the conclusion that in tyranny complicity, equality and fellowship appear as extremely false. The most effective antidote, vis-à-vis these deviations as a way to regain the forgotten freedom, is the proper exercise of friendship. The relevancy of the Discourse of the Voluntary Servitude for today relies on the fact that it offers a perennial paradigm for analyzing any type of tyrant exercise.

Keywords: Ambiguity. Power. Freedom. Friendship. Voluntary. Servitude.

\section{INTRODUÇÃO}

À luz do tratamento dispensado ao tema do poder e da liberdade nas páginas do Discurso da Servidão Voluntária de Etienne de La Boétie, o presente artigo oferece uma singela reflexão sobre as ambiguidades que rondam o Discurso da Servidão Voluntária, tais como o seu ambiente próprio, eivado de transformações sociais, políticas e econômicas numa sociedade que se opunha, em grande parte, ao desvencilhamento do feudalismo. Também considera a questão enigmática da obra de La Boétie, fio condutor da obra, que é a servidão voluntária. A obra de Etienne de La Boétie pode perpetuar-se na análise dos apoios da tirania. Desta forma, são analisadas as bases das relações de força que dão sustentação ao poder tirano, tais como a dominação, o encantamento, a força dos cúmplices e a força e palavra do nome de $U m$. Ademais, refletir sobre os meandros da tirania é oferecer subsídio ao leitor no discernimento do verdadeiro bem comum.

O Discurso da Servidão Voluntária, mais que um catecismo para revoltas populares, é uma exaltação à liberdade. A sabedoria que permite decifrar as mistificações da tirania, ler sua engenharia e projetar suas estratégias, 
recobrando a liberdade esquecida, é sinalizada quando o autor escreve que a tirania não permite acesso aos livros. Para além de um esforço de reeducação do povo, convém retomar uma outra perspectiva educacional e uma nova ética da amizade como meios para o exercício da liberdade e, além disso, da política. A politização da amizade permite lançar-se na busca de uma nova maneira de agir, mais livre e desvinculada da apropriação narcisista do outro.

\section{As ambiguidades de La Boétie}

Armando Ferrari quando descreve o quadro político do Século XVI, lança as seguintes questões a respeito do Discurso da Servidão Voluntária: “Terá o significado histórico do discurso sobre a 'Servidão Voluntária’ apagado o valor intrínseco da obra, ou seria então a exaltação da mesma a causa de uma minimização de sua mensagem?” (FERRARI, 1955, p. 2-3).

O Discurso da Servidão Voluntária, de Etienne de La Boétie, é envolto em grandes acontecimentos que marcam, no fim do Século XV e princípio do XVI, o início de uma nova ordem política no Continente Europeu. ${ }^{1}$ A superação dos esquemas rígidos, próprios do mundo medieval, abre caminho para uma nova concepção de vida. Após um longo período entre o esplendor greco-romano da Antiguidade, seguiu-se o obscurantismo ${ }^{2}$ medieval que antecedeu as inusitadas transformações do Renascimento. Na esteira destas transformações encontram-se a "[...] formação dos estados modernos, que surgem paralelamente ao conceito de nacionalidade; secularização da política e reelaboração da idéia democrática, tendo como primeira consequência uma transformação radical nas relações internacionais” (FERRARI, 1955, p. 4).

\footnotetext{
No devir ideológico da Europa ocidental nenhuma Idade Média se intercala, nenhum Renascimento se interpõe. Este começo do século XVI traz incrustado um sistema sociocultural, amiúde reconstruído, mas mal assente e a estoirar por todos os lados, que se esforça, numa ambiguidade e fraqueza cada vez maiores, por justificar a ordem feudal. Ora, no próprio seio desse sistema surgem acontecimentos - práticas quotidianas, invenções e descobertas (desde a América ao heliocentrismo) - que imperiosamente requerem um reajustamento do discurso legitimante (CHÂTELET, 1983, p. 15).

2 Certos de terem regenerado a língua latina, os humanistas do século XVI acabaram por confundir a segunda e a terceira dessas fases numa só idade de decadência, designando-a Média ou Intermediária. Os historiadores, por sua vez, apropriando-se acriticamente desse instrumental, passaram a ver os séculos medievais como intercalares do ponto de vista da civilização e, a partir do século XVII, o termo Idade Média generalizou-se, carregando consigo aquela conotação de “decadência” (INÁCIO; DE LUCA, 1994, p. 8-9).
} 
Com o vigor renascentista sucumbiam as produções medievais, sobretudo os influxos da escolástica tomista, propondo novas bases para as relações homem-Deus e homem-natureza. Personagens antigos tornam-se personagens atuais, que têm sua expressão ampliada, por exemplo, no Discurso da Servidão Voluntária ${ }^{3}$ de Etienne de La Boétie. Sobre este panorama tradicional e agitado pelas transformações éticas-políticas é que se coloca, na primeira metade do século XVI, o jovem La Boétie e sua crítica à tirania na roupagem da servidão voluntária.

No conjunto político do século XVI, o Discurso da Servidão Voluntária retrata uma postura antimonarquista dos anos $1560:{ }^{4}$ sob a caricatura dos tiranos de outrora transparece a condenação categórica, sem possibilidade

3 O Discurso da Servidão Voluntária possui a maestria dos escritos do século XVI francês e está povoado com todos os recursos formais e materiais de seu tempo: o uso das antíteses e da amplificação, das metáforas médicas, os exemplos históricos cuidadosamente escolhidos e distribuídos de acordo com o mais rigoroso cânone retórico, a descrição do corpo político empregando recursos maneiristas, a definição da Amizade proveniente de Aristóteles, Cícero e Plutarco, a descrição da solidão temerosa em que vive o tirano, oriunda de Xenofonte e de Plutarco, ou de seu arbítrio criminoso, à maneira de Tácito, a referência ao Grande Turco, obrigatória em todos os textos políticos da Renascença, a dúvida quanto ao caráter republicano da monarquia, retirada de Cícero e de Tácito, dúvida presente em todos os textos do humanismo cívico. Como não pensar em Plutarco e em Xenofonte quando vemos a educação comparada ao cultivo das plantas e ao cuidado com as frágeis sementes para que não caiam em mau terreno? CHAUÍ, Marilena. Amizade, recusa do servir, in: Discurso da servidão voluntária, Etienne de La Boétie; (comentários) Pierre Clastres, Claude Lefort, Marilena Chauí; tradução Laymert Garcia dos Santos, São Paulo: Brasiliense, 1999, p. 185.

4 Pouco importa saber se La Boétie, com 16 ou 18 anos, tinha se aventurado em algum clássico exercício escolar sobre o tema da tirania antiga. O que conta é o texto que deixa em sua morte, em 1563, e que o próprio Montaigne julga não poder ser publicável em 1570: obra explosiva, de um assunto da atualidade que convém evitar e de inegável maturidade, o Discurso da Servidão Voluntária data necessariamente dos anos consecutivos à entrada em função de La Boétie no Parlamento de Bordeaux (maio de 1554) e, em sua forma acabada, sem dúvida somente dos anos 1560 subsequentes. Por amizade, por solidariedade, também, com todo o clã parlamentar, Montaigne prefere ocultar a participação de La Boétie em uma corrente de pensamento já preocupante, suavizando a obra de seu amigo, apresentada como simples compilação de estudante. Jamais, pelo menos no século XVI, se mudou a mentira em virtude, mesmo o de Thou (ele também, a fim de neutralizar este escândalo incendiário, quis que o Discurso da Servidão Voluntária fosse aceito como uma obra de juventude e de circunstância). Montaigne não escapa a esta censura de querer, conscientemente, enganar a posteridade. Não é porque se admira o autor dos Ensaios, que será preciso tomar seus ditos como palavra de pura verdade, e não ficar impassível quando ele, abertamente, faz pouco caso de seu leitor. É preciso realmente ver Montaigne e De Thou, ambos da elite parlamentar, como únicas fontes de atribuição de data, e que, a partir do momento em que a gente os recusa, nada se opõe a uma data tardia do Discurso da Servidão Voluntária. 
de recusa da monarquia francesa, tal qual funcionava na metade do século XVI. Sem fornecer algo construtivo, o Discurso da Servidão Voluntária mina todo o sistema monárquico francês, colocando, casualmente em dúvida, o fundamento do direito divino, a legítima transmissão hereditária do trono, a mística do sagrado, a função do Conselho do Rei e a justificação da autoridade pela defesa do bem público, dada como simples pretexto. La Boétie não escreve para a multidão, mas para as pessoas de seu meio, de sua classe política, que apreciarão ainda mais um pensamento radical (KEOHANE, 1977, p. 119-130) pelo fato de ornar-se com remissões à cultura antiga e afirmar-se com uma sutileza de boa companhia, donde advém uma certa arte da esquiva sob ditos irônicos, ${ }^{5}$ bem como o emprego de palavras-chave com duplo sentido tais como "tirano”, "povo”, "liberdade”, "servidão”, que só os neófitos sabiam interpretar com conhecimento de causa.

O Discurso da Servidão Voluntária parece ser uma obra representativa, em torno de 1561, da ousadia das mentalidades parlamentares e do modo de circulação, ainda confidencial, de ideias elitistas, até adquirir o jeito de um verdadeiro panfleto, dirigido não somente contra o absolutismo real, mas contra a própria essência do princípio monárquico. A verdade é que existe, a partir da metade do século XVI, um antagonismo profundo e visceral, entre a concepção monárquica e o desejo de autoridade dos magistrados: o golpe silencioso de 1572 malogrará, o de 1648-1649 igualmente falhará, mas será necessário reconhecer que o de 1787-1789 se realizará de uma forma mais do que suficiente, levando os Parlamentos com o rei.

5 Por exemplo: Dá pena ouvir falar de quantas coisas os tiranos do passado utilizavam para fundar sua tirania, de quantas mesquinharias se serviam, encontrando essa populaça sempre às ordens [...].[...] Os nossos semearam na França algo parecido: sapos, flores-de-lis, a âmbula e a auriflama; o que de minha parte, não importa o que seja, não quero ainda descrer, pois até agora nem nós nem nossos antepassados tivemos ocasião para suspeitar, pois sempre tivemos reis tão bons na paz e tão intrépidos na guerra que, embora nasçam reis, parece que não foram feitos como os outros pela natureza, mas escolhidos de nascer por Deus todo-poderoso para o governo e proteção do reino. E ainda que assim não fosse, não gostaria de entrar na liça por causa disso para discutir a verdade de nossas histórias nem descascá-las tão intimamente, para não tolher esse belo jogo onde nossa poesia francesa poderá esgrimir-se bem... eu a prejudicaria muito se agora dela suprimisse os belos contos do rei Clóvis, nos quais parece-me que já vejo quão prazerosamente, quão à vontade alegrar-se-á a veia de nosso Ronsard em sua Francíade. LA BOÉTIE, Etienne de. Discurso da servidão voluntária, (comentários) Pierre Clastres, Claude Lefort, Marilena Chauí; Tradução de Laymert Garcia dos Santos, São Paulo: Brasiliense, 1999, p. 29-30. Admirável o elegante ceticismo de La Boétie, e sua saborosa ironia com relação a Ronsard. A consagração de Carlos IX é de 15 de maio de 1561. Sobre o legendário monarca, conferir BLOCH, 1993, p. 259-263. Igualmente admirável o fato de que não seja feita aí nenhuma alusão à impertinente liberdade de julgamento de La Boétie. 
La Boétie analisa e pontua inúmeras razões para a servidão tais como o costume, o acovardamento dos sujeitados, o temor do desconhecido e uma cadeia hierarquizada do que ele chamou de tiranetes, talvez o apontamento mais preciso para a nascente estrutura institucional do Estado Moderno. ${ }^{6}$

La Boétie antepõe à tirania a amizade, como sendo o meio capaz de confrontá-la, senão exterminá-la. ${ }^{7}$ A partir daí ganha espaço a oposição entre dois modelos distintos de sociedade, ou seja, um em que a relação das pessoas é

6 No capítulo V de sua obra, Crouzet trata das novas estruturas da Europa e do nascimento do Estado Moderno. Ao percorrer as últimas décadas do Século XV, muitas respostas procuradas anteriormente são encontradas. Uma sociedade rejuvenescida em sua hierarquia, um Estado consolidado, uma economia estimulada pela restauração da ordem pública e pela ampliação do mercado dentre outros, dão um novo impulso a uma civilização ocidental que recobra sua coesão e sua unidade. Alguns pontos são considerados por Crouzet no nascimento do Estado Moderno: a concentração de territórios; a concentração política; o Estado e a estrutura social. Assim ele esboça estes passos: No decurso da segunda metade do século XV, o Estado monárquico desembaraça-se do mundo senhorial, ultrapassando os três obstáculos que entravavam sua marcha: ruptura das hierarquias tradicionais, compartimentação da Cristandade, necessidade de enfrentar novas e múltiplas tarefas com meios limitados. No quadro das nações que se afrontam, ele dilata sua unidade. Chamado a concentrar em suas mãos o exercício da administração e o uso da força, agrupa ou cria os instrumentos da autoridade. Encontra, enfim, no enfraquecimento político e econômico dos antigos quadros sociais, bem como no concurso das burguesias e das novas nobrezas, os meios de reduzir à obediência os membros do corpo social e de transformá-los em seus súditos. [...] A mão do Estado manifesta-se também através de sua justiça. Sem grandes modificações, torna-se mais frequente a intervenção dos homens do rei: a pretexto de aproximar a justiça dos justiçáveis, os juízes não lhes dão trégua; na intenção de simplificar sua tarefa, a lei e o processo tendem à uniformização. Henrique VII quase não inovou, contentando-se em retirar da esclerose instituições já experimentadas. Na França, a grande ordenança de Montilz-lès-Tours, promulgada imediatamente após a guerra (1454) e primeiro monumento moderno da organização judiciária, pretendia ao mesmo tempo ser um estatuto administrativo e um código de processo. Depois, inaugurados pela redação dos costumes da Borgonha (1459), a fixação dos usos locais e a extensão do campo de aplicação do Costume de Paris pareciam esboçar a unificação jurídica em que, possivelmente, Luís XI já pensava. Emanações do Parlamento de Paris, ele próprio outrora resultante da Curia Regis, os Parlamentos recentemente instituídos em Tolouse, Grenoble, Bordéus e Dijon, a manutenção do Erário de Ruão e da Corte de Aix completavam a ingerência do Estado na vida cotidiana dos seus súditos. [...] Nestas condições, o Estado pode impor ou fazer aceitar sua autoridade por todas as categorias sociais. Impôs-se à antiga nobreza feudal, disciplinada doravante pela vontade do príncipe e enfraquecida, aliás, pelo fogo das forças econômicas. [...] As questões religiosas tornavam-se questões de Estado. A autoridade monárquica não realizaria tão rápidos progressos, se não houvesse imposto a sua tutela às cidades e beneficiado do concurso da burguesia. CROUZET, 1977, Tomo III, p. 106-111.

7 Não pode haver amizade onde está a crueldade, onde está a deslealdade, onde está a injustiça; e entre os maus, quando se juntam, há uma conspiração, não uma companhia; eles não se entreamam, mas se entre-temem; não são amigos, mas cúmplices. LA BOÉTIE, 1999, p. 35-36.

Rev. Filos., Aurora, Curitiba, v. 21, n. 28, p. 165-191, jan./jun. 2009 
baseada na conspiração e outro em que a relação é baseada na companhia; um em que elas se entretemem e outro em que se entreamam; um em que são cúmplices e outro em que são amigos - servidão e amizade são excludentes.

Montaigne acrescentaria, no entanto, que La Boétie era obediente às leis e que se preocupava mais em extinguir do que propagar perturbações e ideias novas. Percebe-se um inequívoco esforço de domesticação do Discurso da Servidão Voluntária. Em favor de Montaigne, entretanto, pesa uma preocupação de afastar a obra de La Boétie das intenções partidárias, caracterizando-o como exercício escolar e obra retórica, o que também significava recuperar a complexidade e as nuances abandonadas pelas leituras simplistas, subordinadas à luta política imediata. Talvez este movimento ambíguo de louvor e de depreciação do Discurso da Servidão Voluntária revele um efeito em Montaigne que testemunha de maneira singular o poder provocador da questão colocada pela obra do amigo La Boétie. A lealdade à monarquia e ao catolicismo, do qual La Boétie dará provas durante sua curta e ativa carreira de magistrado no parlamento de Bordeaux, se encarrega de desvencilhar o Discurso da Servidão Voluntária de qualquer intencionalidade subversiva. ${ }^{8}$

O Discurso da Servidão Voluntária conserva todo seu enigma, pois ele diz exatamente, o preto no branco, que a liberdade é natural ao homem. Além disso, ele apela à razão humana e se surpreende, com insistência, da inclinação à servidão, auxiliando os povos incapazes de alguma compreensão. ${ }^{9}$ A dominação política nada tem de natural e isto éum fato irreversível em La Boétie. A posterioridade interpretou (CHAUÍ, p. 179, 1999), na maior parte das vezes, estas censuras e estes questionamentos como um apelo à liberação da opressão. Lamennais fora feliz ao redigir um prefácio à edição do Discurso da Servidão Voluntária em

8 Mas há um outro argumento definitivo a propósito desta aparente antinomia existente em La Boétie, um argumento que se impõe pela simplicidade: o discurso sobre a "Servidão Voluntária" era conhecido, lido por todos sob a forma de manuscrito e usado como arma por agitadores, quando o autor estava vivo, e entretanto ele jamais se sentiu na obrigação, “como cidadão leal e submisso à coroa”, de desmenti-lo e de assim desmentir-se. E não nos digam que essa atitude representava mera pose de literato, numa época em que não havia praça em que no lugar da árvore da liberdade não se visse a sombra da forca (FERRARI, 1955, p. 42).

9 Pobres e miseráveis povos insanos, nações obstinadas em vossos males e cegas em vossos bens, vocês deixam com que levem, diante de vós, o mais belo e o mais puro e transparente de vossas rendas, saqueiem vossos campos, roubem vossas casas e despi-las dos móveis antigos e paternais! Aquele que vos domina tanto tem apenas dois olhos, duas mãos, tem apenas um corpo, e tem apenas uma coisa que o menor homem do grande e infinito número de nossas cidades tem, a não ser a vantagem que vocês lhe dão para vos destruir. LA BOETIE, Etienne de. Discours de la Servitude Volontaire. Chronologie, introduction, bibliographie et notes par GOYARD-FABRE, 1983, p. 138. 
1835 e exemplifica esta perspectiva, fazendo de La Boétie o companheiro de todas as lutas contra a tirania, contra o despotismo e a favor da liberdade. Em seguida, Auguste Valmorel o qualifica de patriota democrata, Gustav Landauer considera que ele é o precursor da anarquia. Mais próximo no tempo, Pierre Clastres vê, na observação etnológica das sociedades sem Estado, a concretização das palavras de La Boétie. Deste fato, soaria natural que, hodiernamente, La Boétie pudesse figurar no panteão de um pensamento político libertário. No entanto, paira uma desconfiança quando se leva em consideração que a luta contra o despotismo, contra a tirania, contra a opressão, contra o poder, contra o Estado, enfim, luta a favor da liberdade, pode afirmar muitas coisas e, ao mesmo tempo, nada de preciso. Etienne de La Boétie eleva-se, certamente, contra a clássica figura do tirano, mas não propõe um discurso contra toda forma de autoridade política. ${ }^{10}$

Nada indica, com exatidão, que La Boétie se reencontrasse no discurso das sociedades sem Estado ou neste, libertário, da redução do Estado e de suas funções a um bem material ou moral que se torna menor. $\mathrm{O}$ questionamento recepciona uma tese mais preciosa que esta crítica, ou seja, a ideia que a dominação política nada tem de natural. Contra todos os usos da categoria de natureza, em que se estabelece a desigualdade política, hoje como outrora, La Boétie faz parte dos felizardos que associaram a natureza à liberdade, transformando-a, assim, em categoria política emancipadora.

La Boétie distancia-se com o seu Discurso da Servidão Voluntária da tradição política é para combatê-la, para opor-se radicalmente ao próprio significado da servidão, o panegírico sempre recomeçado da tirania, sob as inúmeras formas que esta pode adquirir. Este gesto de ruptura guarda uma dupla afirmação, forçosamente escandalosa aos olhos de todos aqueles que, tanto em seu contexto quanto hoje, afirmaram-se ou afirmam-se vitoriosos da ordem estabelecida. ${ }^{11}$ Mas o escândalo maior ainda advém de uma

10 [...] a natureza, [...] deu-nos a todos a terra inteira por morada, alojou-nos todos na mesma casa, figurou-nos todos no mesmo padrão, para que cada um pudesse mirar-se e quase reconhecer um no outro; se ela nos deu a todos o grande presente da voz e da fala para convivermos e confraternizarmos mais, e fazermos, através da declaração comum e mútua de nossos pensamentos, uma comunhão de nossas vontades; e se tratou por todos os meios de estreitar e apertar tão forte o nó de nossa aliança e sociedade; se em todas as coisas mostrou que ela não queria tanto fazer-nos todos unidos, mas todos uns - não se deve duvidar de que sejamos todos naturalmente livres, pois somos todos companheiros [...]. (LA BOÉTIE, 1999, p. 17).

11 O fato de La Boétie ter sido, no âmbito de sua atividade política, um oficial exemplar do rei, não autoriza, de forma alguma, que se minimize o alcance do Discurso da Servidão Voluntária, mesmo se, evidentemente, esta dicotomia entre reflexão e ação não deixasse de ser um problema. Sobre o papel político desempenhado por La Boétie, conferir F. HINCKER e, sobretudo, M. SMITH, apresentação de Mémoire sur la Pacification des troubles, Genebra, 1983. 
constatação que supõe uma inversão total de perspectiva na observação do político, e a tirania não é mais considerada a partir da instância do poder, mas a partir da massa dos dominados.

O reforço de uma leitura situada no território do incômodo e do maldito pode ser retratada na introdução publicada por Simone Goyard-Fabre, que integra a edição do Discurso da Servidão Voluntária publicada em 1983. Goyard-Fabre se recusa a interpretar a obra de La Boétie como uma crítica do poder político ou do fenômeno político. Para ela, o Discurso da Servidão Voluntária, apesar de propor uma reflexão filosófica sobre a essência do político, visa unicamente "[...] exprimir o estatuto político do Estado moderno em vias de se afirmar.” (GOYARD-FABRE, 1983, p. 73). La Boétie dirige seu arsenal crítico para o tirano, na medida em que este contradiz a essência do político, postula Goyard-Fabre. O problema colocado não seria o do poder político, mas o do mau exercício do poder.

No bojo da tradição política, encontra-se também a leitura dedicada a relativizar o alcance "revolucionário" do Discurso da Servidão Voluntária. Esta leitura visa desativar o impacto indissociavelmente político e problemático do texto. A operação consiste em acobertar o escândalo, a neutralizar, por todos os meios, a força subversiva do texto, a negar o que constitui um acontecimento. Sainte-Beuve, em 1853, tentava já restaurar o enfoque da obra como mero exercício literário, retórico e declamatório, buscando opor-se à apropriação militante da obra (SAINT-BEUVE, 1926, p. 139-161). Na toada de Sainte-Beuve estão Gustave Lanson ${ }^{12}$ e Paul Bonnefon.

Paul Bonnefon, precioso desbravador do conjunto da obra de La Boétie, seguiu caminho similar da desqualificação política e filosófica da obra. Para ele o texto é escrito em uma linguagem viva e um colorido que escondem um fundo pobre de ideias. Não totalmente avesso ao caráter incômodo do texto, Bonnefon acusa La Boétie de eximir-se de distinguir a autoridade exercida legitimamente da autoridade ilícita, além de ter sido desleixado nas críticas ao princípio da autoridade (BONNEFON, 1967, p. 43).

12 [...] nada mais inocente que este pastiche, onde se refletem todas as leituras de um jovem entusiasta; onde a paixão antiga da liberdade, o espírito das democracias gregas e da república romana, dos tiranicidas e dos retóricos, tudo se mistura confusamente e a alma do autor se enche e transborda numa áspera declamação. LANSON, 1909. p. 121. 
Noutras vias, o Discurso da Servidão Voluntária fora interpretado como a simples reprodução dos modelos antigos nos quais se inspirou (DELARUELLE, 1910, p. 34-72) ou como um texto precursor das teorias políticas modernas ${ }^{13}$ ou, ainda, como um reflexo da conjuntura histórica, tais como a revolta das Guianas, as revoltas religiosas e a ascensão do absolutismo. Cada uma destas interpretações pode não ser falsa, mas insuficiente, a medida em que o texto ultrapassa todos os dados que, efetivamente, contribuíram para sua produção, e rompe com a continuidade histórica da tradição na qual insere-se. O paradoxo da servidão voluntária tal como La Boétie o formula, não se encontra em nenhum outro lugar nas doutrinas políticas anteriores.

Percorrendo um caminho mais instigante, o Discurso da Servidão Voluntária parece não oferecer nenhuma solução à servidão voluntária e, ao mesmo tempo, ele designa uma. Para alguns, a solução está na legalidade, para outros, na insurreição revolucionária. Após a circulação do "[...] ensaio em mão de gente séria, entre a qual goza de grande reputação [...],” (MONTAIGNE, 2004, p. 178) o Discurso da Servidão Voluntária recebeu as mais opostas interpretações políticas. Convocado para apoiar todos nas solicitações à insurreição revolucionária, La Boétie tivera para outros tantos apenas um único lema na teoria como na prática: Pax et lex. Assim, enquanto Claude Lefort constata que "[...] na obra de La Boétie, não há nenhuma alusão às instituições de um regime livre, não só ao governo, às leis, mas aos costumes que seriam os de um povo livre.” (LEFORT, 1999, p. 171). Pierre Mesnard faz dele o apólogo da legalidade (MESNARD, 1977) e GoyardFabre faz dele o anunciador de uma nova filosofia do direito político, buscando expressar o estatuto político do Estado Moderno em fase de afirmação.

O fator da degenerescência dos regimes tirânicos parece residir, de preferência, na tensão contraditória e insolúvel, entre a unidade para a qual tende o governo dos homens e o pluralismo e personalismo sobre os quais descansa a liberdade. Mas, a questão de La Boétie é saber como preservar, apesar de toda a liberdade, a identidade e a integridade de cada um. Ele busca, portanto, fundar a unidade não sobre o poder, mas sobre o reconhecimento mútuo dos semelhantes, destinando ao governo uma simples função de garantia, de preservação. A partir deste momento percebe-se o porquê de sua recusa

\footnotetext{
${ }_{13}$ Pierre Mesnard e, mais recentemente, Simone Goyard-Fabre consideram o Discurso da Servidão Voluntária como um dos textos inspiradores das teorias modernas da soberania. MESNARD, 1977, p. 406; GOYARD-FABRE, 1983. p. 102.
} 
em debater formas de devolução do poder. Porque elas simulam resolver, magicamente, a contradição que a ciência política, na realidade, esquiva. Reconhecer qualquer legitimidade ao povo em sua totalidade ou a uma fração deste, seja ela a mais esclarecida, ${ }^{14}$ parece não trazer uma solução. Nenhum tipo de organização do poder pode solucionar, de forma definitiva, essa situação conflituosa. É verdade, entretanto, que os regimes políticos não são equivalentes com relação a suas tendências a gerar a tirania. Mas, a existência de mecanismos de sanção dos governantes interessa mais do que a maneira de selecioná-los. Pelo fato da tirania excluir, a priori, a sanção do governante, a monarquia hereditária e absoluta é tirânica por vocação.

Convém atualizar esta tensão permanente que existe no centro do poder político: ela revela algo essencial, que é a necessidade de instituir não o povo propriamente dito, mas aqueles homens capazes de liberdade, justamente porque a amizade lhes possibilita um exercício político de seus direitos sob a configuração política que os governa. Esta institucionalização passa pelo reconhecimento da liberdade de cada um e, principalmente, da liberdade de opinar.

\section{Das relações de força no discurso da servidão voluntária}

O fenômeno do poder é certamente irredutível a esta ou aquela apreensão histórica. O poder que não é percebido é, de todos, o mais perfeito, aquele cujo processo chegou a um fim. Nele, dominante e dominado são um só, embora continuem como se fossem distintos. A unidade que é identidade perverte a diversidade, não porque a suprime, mas porque a mantém como se ela não se alterasse. Aí está o mistério e a revelação: diversos em um só, ao mesmo tempo, diversos e únicos. A servidão voluntária, tão surpreendente, tão cotidiana e tão enigmática que La Boétie se propõe vasculhar. Seu objetivo é descobrir como se desenvolve esta particular vontade de servir, mostrar que a servidão não faz parte da natureza humana e que a liberdade é um traço essencial desta natureza. ${ }^{15}$

14 Para Simone Goyard-Fabre, ele não pudera reconhecer qualquer capacidade jurídica e política na massa popular. A necessidade de uma instituição do povo, sobre a qual o Discurso da Servidão Voluntária desembocaria, segundo ela, passaria por uma aristocracia de homens judiciosos. Esta opinião parece apoiar-se primeiro na biografia de La Boétie e na verossimilhança para a época, do que na exegese de seu Discurso da Servidão Voluntária. (GOYARD-FABRE, 1983, p. 110).

15 Por conjectura procuremos então, se pudermos achar, como se enraizou tão antes essa obstinada vontade de servir que agora parece que o próprio amor da liberdade não é tão natural. (LA BOÉTIE, 1999, p. 16). 
No intento de decifrar o enigma da servidão voluntária, La Boétie envidará esforços capazes de suscitar algumas respostas e alguns dilemas. Acostumados ${ }^{16}$ à servidão, os homens se acovardam entregando-se mais deliberadamente ao jugo dos tiranos. Isto, escreve La Boétie, é algo que os tiranos manipulam muito bem, comprando a liberdade do povo com jogos, prazeres, espetáculos, entre outros. ${ }^{17}$ Ainda joga um papel importante à fascinação que os tiranos sabem exercer sobre o povo, envolvendo seu poder numa auréola de boas intenções, de belas palavras decoradas, tais como fazer para o "bem público" e o "bem-estar de todos". Como se não bastasse tal façanha, se deve considerar o ar misterioso, quase divino, que torna o tirano deslumbrante diante dos que o servem voluntariamente. Muitos tiranos da Antiguidade questionam La Boétie no Discurso da Servidão Voluntária, achavam bem estranho que os homens pudessem suportar um homem fazendolhes mal. Estes tiranos queriam muito pôr a religião na frente, como anteparo e, se possível, tomar emprestada alguma amostra da divindade para o mantenimento de sua miserável vida (LABOÉTIE, 1999, p. 29-30).

A posição mais assentada de La Boétie para o segredo da tirania é a de que o tirano mantém-se porque toda uma rede de pequenos tiranos ou tiranetes lhe apoia e, por sua vez, se apoiam nele. Com essa rede ininterrupta de colaboradores, La Boétie parece apontar para o que, mais tarde, viria a consolidar o Estado Moderno,$^{18}$ opinião compartilhada na leitura de Simone Goyard-Fabre. O que sustenta o monarca absoluto é essa complexa máquina burocrática de homens dispostos a obedecer e a mandar em nome dele. Por isso, infere-se de $\mathrm{La}$ Boétie que todo o que obedece é porque espera obter algum benefício do tirano, porque espera poder exercer um domínio absoluto sobre uma determinada parcela da sociedade, sobre um determinado grupo de homens.

${ }_{16}$ Mas o costume, que por certo tem em todas as coisas um grande poder sobre nós, não possui em lugar nenhum, virtude tão grande quanto a seguinte: ensinar-nos a servir - e como se diz de Mitridates que se habituou a tomar veneno - para que aprendamos a engolir e não achar amarga a peçonha da servidão. (LA BOÉTIE, 1999, p. 20).

17 Os teatros, os jogos, as farsas, os espetáculos, os gladiadores, os bichos estranhos, as medalhas, os quadros e outras drogas que tais eram para os povos antigos as iscas da servidão, o preço de sua liberdade, as ferramentas da tirania. Os tiranos antigos tinham esse meio, essa prática, esses atrativos para adormecer seus súditos sob o jugo. Assim, achando bonitos esses passatempos, entretidos por um prazer vão que passava diante de seus olhos, os povos abobados acostumavam-se a servir tão totalmente e até pior do que as criancinhas que aprendem a ler vendo as brilhantes imagens dos livros iluminados. (LA BOÉTIE, 1999, p. 27).

18 Estado Moderno - Conferir nota número 9. 
A servidão voluntária da qual trata a obra de La Boétie não é a opressão pela força, mas é o desejo de servir os superiores para ser servido pelos inferiores. É uma teia de relações de força que percorrem verticalmente a sociedade sob a forma de mando e de obediência. A servidão que interessa a La Boétie é a relação pela qual cada um participa, voluntariamente, na instituição do poder de Um. É a alienação que tantos homens, povoações, cidades e nações permitem ao $U m$, o qual, consequentemente, pode pretender ser seu Senhor. Nem terror, nem autoridade, esta dominação que ele chama de tirania é o poder stricto sensu, que governa por intermédio da vontade de outro. La Boétie busca compreender este fenômeno, tão contrário à lei natural, que é propriamente inverossímil. O Um não é ninguém, se não fosse este poder informal de essência econômica que organiza hierarquicamente as nações desde aquele momento em que se transformam em um imenso lar. O $U m^{19}$ não é ninguém porque a tirania fundamenta-se, precisamente, em um sistema de despersonalização, ao qual cada um participa à sua maneira. A servidão voluntária é menos um episódio do que de um estado ${ }^{20}$ do qual dificilmente é possível sair. La Boétie estigmatiza, sob o conceito de tirania, a dominação pessoal de $U m$, que faz da República uma coisa sua e que, de governante, se faz Senhor. La Boétie constrói sua demonstração da vontade de servir a partir desta forma de regime extremo, onde ocorre a veemente negação dos súditos. Mas a asserção é decisiva, pois a característica do político, na soberania do $U m$, consiste em não se apoiar mais em uma relação

19 O Discurso somente faz sentido ao leitor obstinado que não hesita em voltar atrás, sem cessar, naquilo que acredita ter compreendido. Sempre, um novo quadro de leitura se oferece, límpido, nunca definitivo, jogo de pista infernal no labirinto das dúvidas peculiares ao leitor. Também é preciso reconsiderar quem é o Um e de qual encantamento ele procede. Na verdade, o Um não é este “outro" que governa, em qualquer instituição política diferenciada do social, mas sim a ordem na qual e pela qual a multidão dos homens é reconduzida à unidade. E os sucos que digerem as nações, as embriagam e as encantam, são, talvez, a secreção do próprio desejo destas. (ORTIZ, 1998, p. 97).

20 La Boétie preveniu não querer debater “formas de república”, mas a própria essência do poder político. A avalanche de cifras, incursões impressionistas na história e o mito são procedimentos retóricos com uma intenção: dar, a seu intuito, o grau de generalidade que convém a uma teoria do Poder político, de qualquer poder. A servidão voluntária é uma espécie de servidão, a pior e a mais comum; ela está para a violência assim como o gênero está para a espécie. Ela é a nossa. Não dissera ele que a praga era incurável e a doença mortal? É preciso, portanto, decidir-se a acompanhá-lo nesta outra pista: existe em qualquer instituição política uma lógica de evicção e de servidão da pessoa, e a impossível cronologia deste negócio leva a se questionar sobre a própria natureza das relações dos homens entre si. (LA BOÉTIE, 1999, p. 96-97). 
de homens livres e iguais. O poder do Senhor, não importando quais sejam as virtudes, é a própria negação do caráter relacional do político.

La Boétie revela a face obscura da tirania, ou seja, os mecanismos pelos quais a realidade mostra-se à consciência, sistematicamente mascarada. A astúcia de todos os tiranos consiste em gerir a dominação à economia da força, sendo que a história testemunha que eles não deixaram de ter nem imaginação, nem audácia, além de prestigiados suportes. A legitimação da tirania passa pela linguagem, isto é, ocorre a atribuição de títulos e nomes ao tirano. Uma vez estabelecida uma tirania, a linguagem ${ }^{21}$ passa a desempenhar outra função, pois de veículo e avalista da liberdade comum, torna-se o suporte da servidão dos homens ao Um. Sua primeira tarefa consiste, doravante, em celebrar o Um sob a substância do Nome; a tecer, em torno do Nome de Um, a infinita rede da ideologia; a proclamar a univocidade do político e a tornar impossível qualquer discurso de volta, qualquer contradição. O diálogo, na sociedade livre, na sociedade natural, é este meio privilegiado pelo qual cada um reconhece o outro, e se reconhece ele próprio no outro, de tal forma que todos se conhecem mutuamente na liberdade. Pois, o que cada pessoa reconhece em cada um, considerando-se todos os outros, é, antes de tudo, sua própria liberdade. Ao contrário, quando a vontade de servir investe a linguagem, a palavra torna-se instrumento de desconhecimento radical dos outros e de si, do que são todos os homens - seres destinados à liberdade. Considera-se, então, que a linguagem sob o regime da dominação é o meio-termo totalmente disposto da alienação. A própria palavra encontra-se alienada à medida que está desviada, pela vontade, de seu uso natural, que é assegurar a comunicação da liberdade e a comunhão na liberdade.

${ }^{21}$ O próprio tirano trata de outorgar-se títulos para manter o povo adorando seu Nome: Os imperadores romanos também não se esqueceram do seguinte: de comumente tomar o título de Tribuno do povo, tanto porque esse ofício era considerado santo e sagrado como porque era estabelecido para a defesa e proteção do povo. E o Nome encobre os efeitos reais da tirania. E por meio dos favores desse ofício assegurava-se de que o povo confiaria mais neles, como se dele devessem ouvir o nome e não, ao contrário, sentir os efeitos. O título de "Tribuno do povo” chega a dissimular os atos tirânicos ou, de preferência, a atribuir-lhes uma justificação. Os títulos são a legitimação, a razão suficiente do tirano. Em outras palavras, a tirania não pode se mostrar a descoberto, para que o povo aceite servir, é preciso emprestar-lhe a máscara dos nomes e títulos. É preciso dar-lhe legitimidade, e esta legitimação passa pelo discurso. O argumento mais persuasivo desta sofística da tirania, aquele sobre o qual todos os outros se fundamentam, é a simples invocação dos nomes, títulos e qualidades do príncipe. E, nesta invocação legitimante, a linguagem, contra os fatos, contra a evidência, é autorizada somente por si própria. (LA BOÉTIE, 1999, p. 28). 
La Boétie evoca o poder da linguagem, um poder equívoco, pois ao mesmo tempo é constitutivo da relação política que ele lamenta e instrumento da dominação que ele deplora, além de arma da crítica que ele instaura. A fala e a palavra $^{22}$ que foram concedidas para dar acessibilidade ao saber e resistência à ignorância, aliadas à imagem, são também os instrumentos desta mesma ignorância. O poder é exercido, assim, por intermédio de vontades que se encadeiam a ele, pelo simples poder da imagem e da palavra. A perplexidade de La Boétie, ao ver um milhão de homens servir miseravelmente encantados pelo nome de Um só, é seguida pelo silêncio voluntário dos povos. O tirano, nome de Um, ressoa no silêncio dos que suportam. $\mathrm{O}$ tirano "[...] não poderia fazer-lhes mal algum senão quando preferem tolerá-lo a contradizê-lo." ${ }^{23}$ Os homens preferem sofrer a tirania que contradizê-la. Contradizer é, antes de qualquer coisa, replicar, tomar a palavra, responder ao tirano. Contradizer o tirano consistiria, primeiramente, para o povo, em clamar seu sofrimento e, por isso, romper com o encantamento do Nome, cujo poder é tal que os oprimidos parecem nada sentir. Mas este silêncio aparente está carregado de gritos e murmúrios abafados. A proliferação do nome de $U m$ inibe e proíbe qualquer discussão entre as pessoas, qualquer forma de diálogo.

A resposta de La Boétie é contradizer o regime autocrático do Nome, mostrando que sem a ficção do Nome, o tirano não é nada. A contradição é palavra de liberdade. Mas a contradição está em conflito com esta evidência monstruosa da servidão voluntária, e os homens preferem sofrer que contradizer ao tirano, são desejosos de tolerar o tirano. "Mas, ó Deus, o que pode ser isso? Como diremos que isso se chama? Que infortúnio é este?.” (LA BOÉTIE, 1999, p. 12). É um vício “[...] que ainda não merece o título de covardia, que não encontra um nome feio o bastante [...]”, (LA BOÉTIE, 1999, p. 13) pior que todos os outros, sendo gerador, no homem, do desejo de servidão. Não há palavra

22 [...] se ela nos deu a todos o grande presente da voz e da fala para convivermos e confraternizarmos mais, e fazermos, através da declaração comum e mútua de nossos pensamentos, uma comunhão de nossas vontades [...]. Ora, comumente, ficam sem efeito o bom zelo e afeição dos que apesar do tempo conservaram a devoção à franquia, por mais numerosos que sejam, porque não se conhecem; sob o tirano, é-lhes tirada toda a liberdade de fazer, de falar, e quase de pensar: todos se tornam singulares em suas fantasias. (LA BOÉTIE, 1999, p. 17-24).

${ }^{23}$ Montaigne dera como possível origem do Discurso da Servidão Voluntária, uma reflexão sobre uma passagem de Plutarco (Sobre a falsa vergonha), onde a falta de uma palavra na língua dos Persas para expressar a recusa é invocada para compreender suas servidões: Assim o que nos diz dos habitantes da Ásia, que sempre serviram a um só senhor por não saberem pronunciar a palavra "não”, foi sem dúvida o que inspirou a La Boétie sua obra “A Servidão Voluntária”. Mesmo quando cita apenas uma palavra, um ato sem importância da vida de alguém, vale suas reflexões um tratado. (MONTAIGNE, 2004, p. 157). 
para nomear este porquê dos homens preferirem se submeter que contradizer, para nomear aquilo que os fascina no nome de Um.

\section{A liberdade no discurso da servidão voluntária}

La Boétie trata de forma surpreendente no Discurso da Servidão Voluntária a questão da liberdade como consequência da desigualdade entre os homens. Ele não funda a liberdade na igualdade natural, mas na natural desigualdade entre os homens, pois esta não conduz à servidão, mas à amizade, ao reconhecimento mútuo dos que são e se sentem companheiros. ${ }^{24} \mathrm{O}$ Discurso da Servidão Voluntária pode ser apresentado como um ensaio de exaltação à liberdade, pois soa como uma palavra que emana da liberdade e que aspira à liberdade. Consiste num exercício de pensamento que se esforça em compreender, em atualizar as causas da tirania, a fim de se libertar dela e administrar, no horizonte da especulação, no campo das práticas político-sociais, um espaço para o restabelecimento efetivo da liberdade.

O Discurso da Servidão Voluntária não é somente uma obra a favor da liberdade e contra o tirano, ou contra os discursos que são úteis à tirania, mas um questionamento sobre as relações ambivalentes que unem o próprio discurso à liberdade e à servidão. Ao postular o papel da linguagem na instituição e reprodução da tirania, bem como ao se esforçar em atualizar a relação essencial que une a palavra humana à liberdade, La Boétie começa a libertar o discurso político da autoridade e da dominação. As considerações sobre a linguagem que o texto contém mostram-se imprescindíveis para compreensão e produção do próprio Discurso da Servidão Voluntária, que provém do desejo de liberdade e tenta libertar-se do papel atribuído à linguagem pela tirania, numa época ${ }^{25}$ onde a eloquência está quase toda a serviço da

24 Mas, por certo, se há algo claro e notório na natureza, e ao qual não se pode ser cego, é que a natureza, ministra de deus e governante dos homens, fez-nos todos da mesma forma e, ao que parece, na mesma forma, para que nos entreconhecêssemos todos como companheiros, ou melhor, como irmãos. [...] não se deve duvidar de que sejamos todos naturalmente livres, pois somos todos companheiros; e não pode cair no entendimento de ninguém que a natureza tenha posto algum em servidão, tendo-nos posto todos em companhia (LA BOÉTIE, 1999, p. 17).

25 Em sociedades com intensa vida pública, como acontecia na sociedade do Antigo Regime, o teatro e a rua mostram diversas semelhanças. Atuar, jogar e agir, exigem a existência de convenções, de artifícios e de teatralidade. São sociedades que valorizam a distância, a impessoalidade, a aparência, a civilidade, a urbanidade, a polidez, a máscara, a teatralidade, o jogo, a ação, a imaginação e a duplicidade, ao invés da autenticidade, da intimidade, da sinceridade, da transparência, da unicidade, da personalidade, e da efusão do sentimento característico das sociedades cuja vida pública foi erodida. A teatralidade e a intimidade se opõem (ORTEGA, 2004, p. 145-156). 
dominação e mostra-se uma das revoltas mais evidentes do desejo de servir. A liberdade, entendida como comunhão de todas as vontades individuais por intermédio do uso comum da palavra, tem, portanto, um sentido eminentemente político ${ }^{26}$ É, em primeiro lugar, a cidade ou uma determinada comunidade humana que é livre. E La Boétie faz, com relação a este assunto, uma observação que incomoda: A revolta da liberdade requer diálogo e conhecimento mútuo, sendo que nos indivíduos que persistem em dedicar um culto à franqueza sob o tirano, quando estão absolutamente separados uns dos outros, as aspirações à liberdade degeneram em fantasia. ${ }^{27}$

A liberdade comum tecida de diálogo e comunicação, somente tem o significado de ser a liberdade de cada um. A igualdade de todos, assim atingida por intermédio da comunicação, nutre-se das diferenças e as deixa existir. A voz provém sempre do indivíduo singular, mas supõe a coletividade, a comunidade dentro da qual cada indivíduo designado tem a palavra. ${ }^{28} \mathrm{~A}$ fala é dada ao homem, juntamente com a razão e uma afeição fraternal, para aperfeiçoar esta sociedade, fazendo dela uma sociedade de pessoas que se entreconhecem e se auxiliam, uma sociedade onde a liberdade se realiza na comunhão das vontades. Decorre disto que a liberdade não é instituída pela política, mas que ela a institui, tornando-se então, do ponto de vista da comunicação, comunhão voluntária. Em outras palavras, esta comunhão é o cumprimento dos desejos da natureza, o pleno reconhecimento pelos homens de seus direitos naturais. A liberdade é considerada como o

${ }^{26}$ La Boétie, e aqui está realmente sua força, não renuncia em pensar, juntamente, liberdade política vivida em comunidade e liberdade metafísica, vivenciada interiormente pelo indivíduo; isto, diferentemente de um teórico moderno do livre arbítrio como Descartes, no qual a moral vem acompanhada se não de uma renúncia, pelo menos de uma indiferença ao político, cuja consequência será a aceitação do absolutismo monárquico como de um estado de fato. É por esta razão que se deve discordar com os comentaristas que, como Nannerl O. Keohane dá sobre a liberdade, a de La Boétie, uma definição estritamente idealista e apolítica, corroboram está posição. Keohane, de fato, resume assim a doutrina da liberdade contida no Discurso da Servidão Voluntária: O essencial é preservar espaço para liberdade de pensamento e de espírito, a única liberdade possível para membros da nossa espécie (KEOHANE, 1980, p. 97).

27 [...] ficam sem efeito o bom zelo e afeição dos que apesar do tempo conservaram a devoção à franquia, por mais numerosos que sejam, porque não se conhecem; sob o tirano, é-lhes tirada toda a liberdade de fazer, de falar, e quase de pensar: todos se tornam singulares em suas fantasias (LA BOÉTIE, 1999, p. 24).

${ }^{28}$ No amparo da liberdade, cada pessoa é útil, assim, para o bem comum, desde que defenda seu bem mais apropriado: Entre gente livre é à porfia, cada qual melhor, cada um pelo bem comum, cada um por si [...] (LA BOÉTIE, 1999, p. 26). 
primeiro destes direitos e a fonte de todos os demais direitos. A sociedade política coincide com a conscientização ao mesmo tempo coletiva e individual, na palavra dialogada, da liberdade como emanação da natureza e a própria essência do homem. Neste sentido, a linguagem é o meio pelo qual o homem tem acesso total à sua própria natureza, que é o ser livre em sociedade. ${ }^{29}$ De fato, nada torna os homens mais submetidos à sua crueldade do que os bens e não há crime algum mais digno de morte do que a posse que ama apenas as riquezas. O poder origina-se, não da posse, ${ }^{30}$ mas da luta pela apropriação dos bens. ${ }^{31}$ Ele origina-se também da ilusão. O desejo do ter é ilusão, pois os homens não se enriquecem na tirania onde tudo pertence a $U m$ e nada é de ninguém.

A liberdade não é um atributo intrínseco à natureza do homem, não mais do que a servidão. A liberdade e a servidão são relação de pessoa para pessoa, de pessoa para instituição, de instituição para instituição. A liberdade é uma relação de igualdade, e a servidão é uma relação hierárquica. No registro do ter, o outro é indiferente ou um meio de aquisição da coisa, porém no registro da liberdade, o outro é o próprio objeto do desejo. Enquanto relação, a igualdade não postula em nada a identidade das partes, mas, pelo contrário e por definição, a existência de um outro, ao mesmo tempo diferente e semelhante. A igualdade

${ }^{29}$ Com efeito, pensando o fato da linguagem, já pensamos a separação e a conjunção dos sujeitos, já pensamos o acontecimento enigmático da liberdade que supõe, com a declaração comum dos pensamentos de cada um a cada um, o instante de um querer falar ao qual em vão procuraríamos as condições num estado anterior e cuja origem não se encontra nem nos indivíduos - pois são uns pelo fato de falarem -, nem fora deles - pois falam um com o outro, um para o outro. Pensando a linguagem já pensamos o político, libertos da ilusão do Um. Pois afirmar que o destino dos homens é de ser não todos unidos, mas todos uns, é trazer a relação social para a comunicação e a expressão recíproca dos agentes que ela só é redutível no imaginário e, no mesmo movimento - não deixemos de assinalar - denunciar a mentira dos governantes que fazem da união de seus súditos ou da dos cidadãos o signo da boa sociedade (LEFORT, 1999, p. 143-144).

30 La Boétie evoca positivamente os bens familiares, o patrimônio... (LA BOÉTIE, 1999, p. 16).

31 [...] La Boétie parece acreditar que basta mostrar aos homens que não sirvam a quem os tiraniza para que se libertem e o colosso se destrua. Porém, já não é sensato pregar isso a quem não reconhece o próprio mal, a quem não pode fazer a anamnese porque sucumbiu ao costume, cuja “virtude é ensinar-nos a servir”. Somente após a descrição dos infortúnios do povo bestializado, iludido e que não luta porque se sabe mais fraco, e a da ambição dos grandes, que servem para mandar, iludidos por bens que não são seus, a amizade reaparece. Agora, porém, não mais como dom da natureza a todos, mas como virtude de alguns (CHAUÍ, 1999, p. 205-206). 
não é identidade, mas reconhecimento do semelhante no outro. ${ }^{32}$ Os únicos atributos intrínsecos da pessoa, a voz e a palavra, somente têm eficácia nesta relação. A liberdade é uma qualidade natural da pessoa por dedução lógica da principal relação de igualdade e de fraternidade. ${ }^{33}$

La Boétie retira, de forma livre e generosa, tudo o que pode servir a seu propósito, mas, sobretudo, exemplos extraídos abundantemente dos livros da literatura clássica, demonstram sua consideração pela cultura livresca como uma cultura da liberdade. Os livros são a memória viva da liberdade. A reconquista da liberdade e da investigação do fenômeno da servidão voluntária, sem a qual este restabelecimento é impensável, passa necessariamente pelos livros e, principalmente, pelos livros de história. Desta forma, o papel que La Boétie atribui à história é eminentemente moderno, quando ele vê aí um meio de compreensão do presente e de antecipação do futuro. ${ }^{34} \mathrm{~A}$ história é uma arma para a ação política.

32 La Boétie insiste no fato que as diferenças de corpo e de espírito estão presentes na natureza: (a natureza) [...], no entanto, não entendeu colocar-nos neste mundo como em um campo cerrado e não enviou para cá os mais fortes nem os mais espertos como bandidos armados numa floresta, para aí dominar os mais fracos; mas, antes, é de se crer que, atribuindo assim as partes maiores a uns, aos outros as menores, queria fazer lugar ao afeto fraternal para que ele tivesse onde ser empregado, tendo uns o poderio de dar ajuda, os outros necessidade de recebê-la (LA BOÉTIE,1999, p. 17).

33 A preocupação com o mundo, ponto central da política desde a Antiguidade foi substituída na modernidade pela preocupação com o homem, a descoberta de si mesmo. Uma preocupação consigo que se traduz na atualidade na preocupação com a saúde e com o corpo, tornado alter ego. Somente desenvolvendo novas formas de amor mundi no sentido arendtiano é que, a meu ver, podemos conceber alternativas a esse ideal, criar e recriar formas de relacionamento voltadas para o mundo, para o espaço público, tais como a amizade, a cortesia, a civilidade, a solidariedade, a hospitalidade, o respeito. Todas elas dependem de uma publicidade, de um espaço de visibilidade capaz de iluminar os acontecimentos humanos, de um modo comum que una ou separe os indivíduos, mantendo sempre a distância entre eles, condição da pluralidade. É nesse sentido que Hannah Arendt contrapõe a amizade à fraternidade no ensaio sobre Lessing em "Homens em tempos sombrios", pois a amizade exprime mais a humanidade do que a fraternidade, precisamente por estar voltada para o público. Ela é um fenômeno político, enquanto que a fraternidade suprime a distância dos homens, transformando a diversidade em singularidade e anulando a pluralidade. A fraternidade é, no fundo, uma forma de comunidade identificatória, na qual, na condição de irmãos, somos todos iguais (ORTEGA, 2004, p. 145-156).

34 Este conceito da história está muito próximo daquele de Maquiavel: “Todos aqueles que me lerem poderão tirar proveito que deve se propor a conhecer a história “ (Discurso sobre a segunda década de Tito Lívio, L. 1, Prefácio). 
La Boétie empresta da Antiguidade, não somente exemplos, mas até comparações e imagens para o Discurso da Servidão Voluntária. ${ }^{35}$ La Boétie parece ter incorporado a ideia de Plutarco, cujas obras traduzira, de que a verdade de uma ação descobre-se na voz daquele que a produz. Se o tirano produz sua verdade, cabe ao povo grosseiro encontrar no entreconhecimento um caminho para contradizer a verdade e a ação tirânicas. A troca proporcionada pelo companheirismo não é somente a condição da formação do pensamento bom e adequado, mas é o próprio objeto do conhecimento útil à liberdade. Este conhecimento não é um saber de uma elite esclarecida sobre o bem da comunidade, mas o entreconhecimento, ou seja, a faculdade de se reconhecer uns nos outros e de conhecer o que é comum a todos..$^{36}$ Não há liberdade fora da troca porque a vontade comum formula-se no diálogo de vontades iguais. A liberdade de uns depende, por consequência, da liberdade dos outros. É por este motivo que a liberdade não é concebível sem um direito à liberdade de opinião e de expressão (LA BOÉTIE, 1999, p. 24-25). A liberdade desabrocha na igualdade, e esta, por sua vez, não é a unidade dos mesmos, mas a paridade dos diferentes. ${ }^{37}$ Como a linguagem, a igualdade conjuga, indefinidamente, o plural e a unidade, o diferente e o comum, a singularidade e a universalidade. Ela postula a capacidade de cada um em reconhecer o outro como outro e semelhante. ${ }^{38}$ Por isso, a amizade impõe-se como fundamento para a liberdade. ${ }^{39}$

35 Associando-se apenas às ideias essenciais, emerge uma sequência lógica da obra. O posicionamento da questão: reflexões prolongadas sobre o que há de paradoxal, de estranho, a escravidão de um milhão de homens a um tirano. As razões que podem explicar esta servidão: 1- o costume; 2covardia causada nas pessoas pela servidão e desenvolvida ainda pelos artifícios dos tiranos; 3interesse que os favoritos e suas próprias criaturas têm para a manutenção da tirania; reflexões sobre o destino miserável e sobre a cegueira destes favoritos (DELARUELLE, 1910, p. 34-72).

36 " "...] uma declaração comum e mútua de nossos pensamentos, uma comunhão de nossas vontades; e se tratou por todos os meios de estreitar e apertar tão forte o nó de nossa aliança e sociedade [...].” (LA BOÉTIE, 1999. p. 17).

37 A multiplicidade e pluralidade das partes introduzem o tema da diferença. Não é concebível uma comunidade política sem diferença: se à comunidade é necessária a dimensão plural dos homens é preciso afirmar que 'tais homens são especificamente diferentes, porque uma polis não pode ser constituída de elementos iguais’. Essa diversidade existe entre os indivíduos e entre as diferentes partes da polis, e possui um caráter qualitativo. [...] Ela é natural e benéfica ao conjunto e a todas as partes, enquanto uma condição de paridade ou de inversão do comando é prejudicial e comporta desagregação (DUSO, 1999, p. 57-58).

${ }^{38} \mathrm{E}$ de resto, se essa boa mãe deu-nos a todos a terra inteira por morada, alojou-nos todos na mesma casa, figurou-nos todos no mesmo padrão, para que cada um pudesse mirar-se e quase reconhecer um no outro; se ela nos deu a todos o grande presente da voz e da fala para convivermos e confraternizarmos mais [...]. (LA BOÉTIE, 1999, p. 17).

39 É certamente por isso que o tirano nunca é amado, nem ama: a amizade é um nome sagrado, é uma coisa santa; ela nunca se entrega senão entre pessoas de bem e só se deixa apanhar por mútua estima; mantém-se não tanto através de benefícios como através de uma via boa; o que torna um amigo seguro do outro é o conhecimento que tem de sua integridade; as garantias que tem são sua bondade natural, a fé e a constância (LA BOÉTIE, 1999, p. 35). 
A bajulação ${ }^{40}$ proporcionada pelos tiranetes é a falsificação da amizade, assim como a conspiração é falsificação da companhia, ${ }^{41}$ a cumplicidade é marca e falsificação da amizade, a unidade é a falsificação da igualdade, cuja marca maior é a própria indiferença. ${ }^{42}$ Por fim, o arbítrio é a falsificação da liberdade, da paz, cuja marca é a analogia, como lembrava Aristóteles na Ética a Nicômaco. ${ }^{43}$

Considerando o desejo de servir a mola propulsora da tirania, o Discurso da Servidão Voluntária demonstra também que os meios da liberdade, ou da servidão, não residem somente nas instituições do governo, mas eles agem por toda à parte na sociedade. Uma vez que a natureza é boa-mãe, a liberdade só pode ser natural, pois a generosidade da natureza nos faz todos iguais e companheiros. Conclui-se que a servidão voluntária ${ }^{44}$ é mau encontro, é supressão da vontade própria assimilando a vontade do tirano como razão. As soluções não dizem respeito somente ao direito, mas também à ética. Elas não envolvem apenas as instituições, mas as pessoas. A liberdade, na realidade, questiona a faculdade dos homens de aceitar, na relação que eles desenvolvem um a um, a alteridade.

O regime de liberdade é determinado pela capacidade de cada um em reconhecer, no outro, o seu semelhante. O enigma do Discurso da Servidão Voluntária deve-se à incapacidade do leitor de esgotar seu significado, assim

40 Sobre a figura do adulador que se aproveita das características peculiares da amizade fundada em natureza (semelhança, comunidade de disposições, costumes e caracteres, benevolência, boa-fé, comunidade de pensamentos, reciprocidade) para mimá-la e pervertê-la pela dissimulação. Conferir Plutarco - De como distinguir um amigo de um adulador, em Moralia, Tomo I, p. 243-337; e Cícero - De Amiticia, XVI, p. 97-99.

41 [...] e entre os maus, quando se juntam, há uma conspiração, não uma companhia; eles não se entre amam, mas se entretemem; não são amigos, mas cúmplices (LA BOÉTIE, 1999, p. 36).

42 E de resto, se essa boa mãe deu-nos a todos a terra inteira por morada, [...] se em todas as coisas mostrou que ela não queria tanto fazer-nos todos unidos, mas todos uns - não se deve duvidar de que sejamos todos naturalmente livres, pois somos todos companheiros; e não pode cair no entendimento de ninguém que a natureza tenha posto algum em servidão, tendonos posto todos em companhia (LA BOÉTIE, 1999, p. 17).

43 Vimos, assim, que a existência de uma pessoa boa é desejável porque ela percebe a sua própria bondade, e uma tal percepção é agradável em si. Ela necessita, portanto, ter consciência igualmente da existência de seu amigo, e isso se verificará se viverem juntos e compartilharem suas discussões e pensamentos; parece ser este o significado de convivência no caso dos homens, e não, como no caso do gado, pastar juntos no mesmo lugar (ARISTÓTELES, 2001, p. 212).

44 Servidão Voluntária é acontecimento que a natureza nega ter produzido e que a língua não pode nomear porque vontade e liberdade sempre foram conceitos indiscerníveis e o que é "por natureza” não pode ser “por constrangimento”, servidão e vontade não podendo andar juntas (CHAUÍ, 1999, p. 191-192). 
como do mistério do poder político, seja o de outrora ou o de agora. La Boétie considera a possibilidade de uma postura filosófica e ética, que se enlaça no que ele chama de entreconhecimento, ou seja, na amizade. ${ }^{45} \mathrm{O}$ entreconhecimento não questiona simplesmente o saber estabelecido, o conhecimento camuflado, mas a qualidade de uma relação com o outro. A liberdade se funda na amizade, a tirania no seu esquecimento. Desta forma, o saber e o conhecimento são condições da liberdade porque são muralhas às ilusões que consolidam a tirania - combatem o esquecimento. Os verdadeiros tiranos a compreendem, pois governam, sempre, por meio da censura e do auto-de-fé dos livros ${ }^{46} \mathrm{O}$ conhecimento é, essencialmente, assunto de entreconhecimento, de palavra e está, portanto, intrinsecamente ligado à liberdade de palavra do outro. Sem a liberdade de expressão juridicamente protegida, a afeição e o zelo emancipador permanecem sem efeito. ${ }^{47}$

Uma das características da tirania é o fato de não admitir a amizade entre os seus membros, justamente porque, na tirania, os súditos não são tratados como livres, mas como escravos, e a relação ocorre unicamente em benefício do tirano. O conhecimento é condição para que o homem se torne mais livre e deixe de ser um sujeito heterônimo, caminhando em direção à escolha das leis que regem sua conduta, governando a si mesmo, tendo liberdade ou independência moral e intelectual, ou seja, tendo autonomia. Somente pode abandonar a atitude servil quem conhece a causa da servidão, quem retoma sua condição de homem, sua voz e palavra ante a força do nome de $U m$. Neste sentido, o conhecimento de si, do “outro" e do mundo são condições para que o homem torne-se livre e desenvolva-se como sujeito autônomo, consciente do seu "ser e estar" no mundo. Segundo La Boétie, cada um fala conforme a educação recebida. No mesmo diapasão, existem alguns homens que sentem o peso do jugo, não se submetem a sujeição, não esquecem seus direitos naturais e esforçam-se por reivindicá-los a cada oportunidade - são eles que, tendo o espírito correto, ainda os retificam, através do estudo e do saber ${ }^{48}$ A não-aceitação da servidão dar-se-ia com aquelas cabeças pensantes, isto é, daqueles sujeitos

45 A amizade, escreve Lefort, nos ensina a dimensão política da leitura. Diremos também que a leitura da obra de La Boétie nos ensina a dimensão política da amizade, recusa do servir (CHAUÍ, 1999, p. 209).

46 O grão-turco percebeu bem isto: que os livros e a doutrina dão aos homens, mais que qualquer outra coisa, o sentido e o entendimento para se reconhecerem e odiar a tirania; averiguo que em suas terras ele não tem sábios, nem os quer (LA BOÉTIE, 1999, p. 24).

47 [...] sob o tirano, é-lhes tirada toda a liberdade de fazer, de falar, e quase de pensar: todos se tornam singulares em suas fantasias. Portanto, Momo, o deus zombeteiro, não zombou demais quando censurou o homem que Vulcano fizera por não lhe ter posto uma janelinha no coração para que por aí se pudessem ver seus pensamentos. (LA BOÉTIE, 1999, p. 24).

48 LA BOÉTIE, 1999, p. 24. 
competentes no uso da razão. Mas eles são um número pequeno quase sempre, e a censura torna seus pensamentos, simplesmente, fantasias singulares, enquanto a maioria sofre de uma doença quase incurável, que é o prazer de servir. ${ }^{49}$

A amizade é praticamente impossível onde está a injustiça, a crueldade e a deslealdade. Se tais coisas são práticas comuns no governo do tirano, há uma distorção da amizade, conjugada como não tirar alguma coisa de alguém, não dever nada a ninguém e não dar ou receber mais do que o devido. Assim compreendida, a amizade ganha uma conotação eminentemente política:

Uma nova política e uma nova ética da amizade devem visar precisamente a encorajar essa vontade de agir, a recuperar um certo apelo iluminista à coragem de pensar de uma forma ainda não-pensada, de sentir e amar de maneira diferente. Trata-se de elaborar uma política da imaginação que aponte para a criação de novas imagens e metáforas para o pensamento, a política e os sentimentos e que renuncie a prescrever uma imagem dominante, pois isso significaria, no fundo, simplesmente substituirmos um imaginário, que se tornou obsoleto, por outro (ORTEGA, 2004, p. 145-156).

Para ser livre, basta desejar. Decidi não mais servir e sereis livres. Seria simples o receituário se não acompanhado do entreconhecimento, desafio medievo e moderno, que unido à necessidade de recuperar a voz e a fala são instrumentos essenciais ao restabelecimento do espaço público, espaço este que permite admitir as diferenças, aceitar o novo e estar aberto ao outro. Este desafio La Boétie parece intencionado propor no seu singelo e juvenil Discurso da Servidão Voluntária, reforçando o companheirismo capaz de ajudar a recobrar a liberdade. ${ }^{50}$

49 Um dos mais antigos usos da palavra “tirania” no pensamento político é sinônimo de soberania. Quando todas as questões se referem a um princípio comum ou a uma pessoa soberana, esse princípio ou essa pessoa tiraniza a vida da sociedade. Esse governo de uma multiplicidade de hábitos e de ações pela autoridade soberana de uma fonte única não precisa ser originada por coerção brutal; pode igualmente surgir por sedução, de tal modo que as pessoas queiram ser governadas por uma autoridade única que se coloque acima delas todas. Esta sedução tampouco precisa envolver uma pessoa enquanto tirano. Uma instituição pode dominar como uma fonte única de autoridade; uma crença pode servir como padrão único para enfrentar a realidade. A intimidade é uma tirania, na vida diária, dessa última espécie. Não é a criação forçada, mas o aparecimento de uma crença num padrão de verdade para se medir as complexidades da realidade social (SENNETT, 1988, p. 411-412).

50 A amizade é um fenômeno público, precisa do mundo, da visibilidade dos assuntos humanos para florescer. Nosso apego exacerbado à interioridade, a 'tirania da intimidade’ não permite o cultivo de uma distância necessária para a amizade, pois o espaço da amizade é o espaço entre os indivíduos, do mundo compartilhado - espaço da liberdade e do risco [...]. Intensificando nossas redes de amizade podemos reinventar o político (SENNETT, 1988, p. 145-156). 
Os riscos de enganos, a intranquilidade, a angústia da decisão e a responsabilidade que a liberdade pode acarretar, fazem com que ela seja considerada antes um pesadelo. Ou seja, ser livre implica medo ou insegurança, cujo resultado pode chegar a uma servidão voluntária. Seria outra a conclusão se a politização da amizade fosse um reconvite a recuperar o espaço público, disseminando aí um amor mundi capaz de solidarizar mais e intimizar menos.

\section{CONCLUSÃO}

A má sorte da obra de La Boétie talvez tenha desempenhado historicamente uma dupla dinâmica, de forma que o Discurso da Servidão Voluntária serviu a propósitos religiosos, anárquicos, libertários, de desobediência civil e outros mais. Esta trajetória irregular da obra de La Boétie é, no mínimo, um aperitivo para a filosofia política em um de seus mais emblemáticos debates, 0 uso do poder. Hoje, o sistema econômico-político neoliberal que o Ocidente tem imposto ao mundo inteiro está vivendo uma crise sem precedentes. Neste princípio de novo milênio, os movimentos de contestação e renovação que aspiram a um outro mundo possível, de matriz ocidental e europeia, estão buscando elementos de uma sensibilidade diferente em âmbitos geopolíticos até agora inexplorados, a fim de mudar seu modo tradicional e obsoleto de se relacionar com a política. Este intuito renova-se e tem um reforço considerável a partir da obra de La Boétie, não instrumentalizada somente como crítica, mas possível visualização de um viés que permita o bom uso do espaço público em vista do bem comum.

Totalitarismo poderia ser o nome atual da "tirania de La Boétie", diluído em uma miríade de controles sociais e dos desejos consumistas, falsas necessidades, etc. O nome de $U m$ é diferente, mas as estratégias de dominação permanecem atualíssimas e, continuadamente, insistentes no seu intento de negar o direito do outro ser “outro", pelos simples interesses econômicos-políticos escusos e necessários ao mantenimento do poder. Os dispositivos de pão e circo, de mistificação religiosa, de encantamento e alienação, que os governantes usam para subjugar os povos e conquistar o seu consentimento, continuam a ser os mesmos tais como apresentados no teor do Discurso da Servidão Voluntária. Frente a esta situação, La Boétie revela a necessidade de despertar a opinião pública para este processo, esta arquitetura que suporta o governo de Um, desmistificando o aparelho estatal tirano. Não é simplesmente educar o público sobre os "erros" cometidos pelo governo tirano, mas desmascarar a natureza e os procedimentos da "tirania". Ao limitar-se à análise dos erros, os 
adversários da intervenção governamental tornam-se ineficazes no combate às tiranias. $\mathrm{O}$ aparato econômico é a principal arma da atualidade, inclusive dando claras provas de que os súditos estão dispostos a dar a vida em favor do tirano.

A ignorância é uma arma permanentemente moderna, potencialmente destrutiva da liberdade e à qual se contrapõe o Discurso da Servidão Voluntária, apostando na capacidade de educar e mobilizar o povo e aqueles que se moldaram pela cultura do saber, contra qualquer forma de esquecimento da liberdade. A obra de La Boétie conduz a uma encruzilhada no mínimo provocativa, sobretudo se for considerado junto com a pessoa humana seu contínuo desejo de liberdade: a lógica do poder é contrária à lógica da liberdade, a cumplicidade dos dominadores é contrária ao companheirismo dos que se sentem iguais. Ele não vê cabimento para mediação entre ambos os tipos de relação social, sendo taxativo ao dizer que o tirano nunca é amado, nem ama, porque a amizade é um nome sagrado que só se entrega entre pessoas de bem. O Discurso da Servidão Voluntária permite olhar para novas maneiras de amar e pensar, antevendo na amizade uma forma de exercício político. Se o momento histórico é de despolitização, cabe tanto ao sábio como ao povo reinventar o ser político, criar novas formas de experienciar a liberdade, novas formas de vida e comunidade, novas formas de sensibilidade e percepção, além, como conclamava em sua obra La Boétie, de intensificar os laços de amizade.

Se para La Boétie o entreconhecimento e o saber seriam possíveis saídas ao vício da servidão voluntária ou às amarras da tirania, o fato é que sua preocupação com as relações de força presentes no corpo social institucionalizado, ou seja, sua reflexão sobre o poder em si, continua mais presente na dinâmica política e relacional atual que antes. Esta característica desinstaladora, versátil e crítica, desvela a incômoda vocação da obra de La Boétie, qual seja, escancarar o problema da dominação das nações.

\section{REFERÊNCIAS}

ARISTÓTELES. Ética a nicômaco. São Paulo: Martin Claret, 2001.

BLOCH, M. Os reis taumaturgos. Tradução de Julia Mainardi. São Paulo: Cia das Letras, 1993.

BONNEFON, P. Oeuvres complètes de La Boétie. Genebra: Slatkine Reprints, 1967.

CHÂTELET, F. A filosofia do mundo novo: século XVI ao século XVII. Lisboa: Publicações Dom Quixote, 1983. 
CHAUÍ, M. Amizade, recusa do servir. In: LA BOÉTIE, E. de. Discurso da servidão voluntária. São Paulo: Brasiliense, 1999. p. 173-239.

CROUZET, M. História geral das civilizações: a Idade Média: os tempos difíceis (Fim). São Paulo; Rio de Janeiro: DIFEL, 1977. v. 3.

DELARUELLE, L. L'inspiration antique dans le discours de la Servitude Volontaire. Revue D'Histoire Littèraire de la France, (R.H.L.), 17 ème année, p. 34-72, 1910.

DUSO, G. La logica del potere: storia concettuale como filosofia política. Roma-Bari: Laterza, 1999.

FERRARI, A. Etienne de La Boétie no quadro político do século XVI. São Paulo: [s.n.], 1955.

GOYARD-FABRE, S. Introduction. In: LA BOÉTIE, E. Discours de la servitude volontaire. Paris: GF Flammarion, 1983.

INÁCIO, I.; DE LUCA, T. R. O pensamento medieval. São Paulo: Ática, 1994.

KEOHANE, N. Philosophy and the state in France. Princeton: Princeton University Press, 1980.

The radical humanism of etienne de La Boétie. Journal of the History of Ideas, Stanford University, v. 38, n. 1, p. 119-130, 1977.

LA BOÉTIE, E de. Discours de la servitude volontaire. Chronologie, introduction, bibliographie et notes par. Paris: Payot, 1976.

Memoire sur la pacification des troubles. Geneva: Droz, 1983.

. Discurso da servidão voluntária ou o contra um. Tradução de Laymert Garcia dos Santos. São Paulo: Brasiliense, 1999.

LANSON, G. Històire de la litterature française. Paris: Hachette, 1909.

LEFORT, C. O nome de um. In: LA BOÉTIE, E de. Discurso da servidão voluntária. São Paulo: Brasiliense, 1999.

MESNARD, P. L'essor de la philosophie politique au XVI siècle. Paris: Librairie Philosophique J. Vrin, Troisième, 1977.

MONTAigne, M. de. Ensaios. Tradução de Sérgio Milliet. São Paulo: Nova Cultural, 2004. 
ORTEGA, F. Por uma ética e uma política da amizade. In: MIRANDA, D. S. de (Org.). Ética e cultura. São Paulo: Perspectiva; SESC São Paulo, 2004. p. 30-35.

ORTIZ, L. Le pouvoir et la liberte dans le discours de la servitude volontaire D’Etienne de La Boétie. In: Pouvoir et Liberté: études offertes a Jacques Mourgeon, Bruylant: Bruxelles, 1998.

SAINTE-BEUVE, C. A. Grands ecrivains Français - XVI siècle: les prosateurs. Paris: Garnier Freres, 1926.

SENNETT, R. O declínio do homem público: as tiranias da intimidade. Tradução de Lygia Araújo Watanabe. São Paulo: Cia das Letras, 1988.

Recebido: 28/11/2008

Received: $11 / 28 / 2008$

Aprovado: 20/12/2008

Approved: $12 / 20 / 2008$

Revisado: 01/10/2009

Reviewed: 10/01/2009 